\title{
PENERAPAN MODEL BOX JENKINS (ARIMA) DALAM PERAMALAN HARGA KONSUMEN BAWANG MERAH DI PROVINSI JAWA TENGAH
}

\author{
Ali Hasyim Al Rosyid ${ }^{1}$, Candarisma Dhanes Noor Viana², Wahyu Adhi Saputro ${ }^{3}$ \\ ${ }^{1}$ Program Studi Agribisnis, Fakultas Pertanian, Universitas Pembangunan Nasional "Veteran" Yogyakarta \\ ${ }^{2}$ Program Studi Agribisnis, Fakultas Pertanian, Universitas Janabadra Yogyakarta \\ ${ }^{3}$ Program Studi Agribisnis, Fakultas Sains dan Teknologi, Universitas Duta Bangsa Surakarta

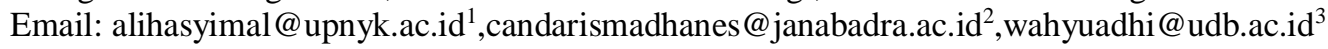

\begin{abstract}
ABSTRAK
Bawang merah merupakan produk pertanian khususnya hortikultura yang memiliki peranan penting di Indonesia dengan dimasukkan sebagai salah satu bahan pangan utama. Permintaan bawang merah yang tinggi dan produksi yang bersifat musiman menjadikan harga bawang merah fluktuatif dan cenderung meningkat setiap tahunnya. Analisis ARIMA adalah salah satu metode yang digunakan untuk peramalan data time series. Tujuan dari penelitian ini adalah untuk peramalan harga konsumen bawang merah di Provinsi Jawa Tengah. Data yang digunakan dalam penelitian ini adalah data harga konsumen bawang merah di Provinsi Jawa Tengah dari aplikasi Pusat Informasi Harga Pangan Strategis (PIHPS) yang diakes pada lama hargapangan.id. Data yang digunakan untuk analisis ARIMA merupakan data harga konsumen bawang merah di Provinsi Jawa Tengah dari Bulan Juli tahun 2017 sampai Bulan April tahun 2021 dengan total jumlah data adalah 46 data harga konsumen. Berdasarkan hasil penelitian dapat disimpulkan bahwa model ARIMA terbaik yang digunakan untuk peramalan harga konsumen bawang merah di Provinsi Jawa Tengah adalah ARIMA c(3,1,2). Model harga konsumen bawang merah di Provinsi Jawa Tengah adalah $\mathrm{D}(\mathrm{Y})=-0.254657 \mathrm{AR}_{(3)^{-}}$ $0.586703 \mathrm{MA}_{(2)}$. Peramalan harga konsumen bawang merah di Provinsi Jawa Tengah sampai Bulan April tahun 2022 dengan menggunakan metode dinamis diperoleh data harga konsumen yang terus meningkat.
\end{abstract}

Kata Kunci: ARIMA, Harga Konsumen Bawang Merah, Peramalan

\section{PENDAHULUAN}

Hortikultura merupakan subsector pertanian yang sangat strategis. Subsector hortikultura memiliki kontribusi yang cukup besar terhadap PDB sektor pertanian yaitu sebesar 11,39\%. Selain itu kontribusi subsektor hortikultura juga memiliki peranan besar terhadap kondisi ekonomi secara makro, tercermin dalam PDB subsektor hortikultura terhadap Produk Domestik Bruto pada tahun 2019 sebesar 1,39\% atau setara dengan 135 triliun rupiah (BPS 2020). Sedangkan pada tahun 2020 diproyeksikan kontribusi subsector hortikultura meningkat menjadi 1,48\% (BPS, 2021)

Bawang merah merupakan salah satu komoditas hortikultura khususnya sayuran dengan jumlah produksi yang tinggi. Pada tahun 2019 produksi bawang merah di Indonesia mencapai 1.580 .247 ton dan jumlah ini relative lebih besar bila dibandingkan dengan produksi komoditas sayuran lainnya seperti produksi cabai merah besar pada tahun 2019 1,2 juta ton dan untuk cabai rawit sebesar 1,3 juta ton.

Konsumen bawang merah di Indonesia merata di seluruh daerah, sementara produksi bawang merah hanya terpusat di daerah-daerah tertentu saja. Berdasarkan produksi bawang merah di Indonesia tahun 2019, daerah dengan produksi tertinggi ada di Pulau Jawa dengan persentase sebesar 68\%. Provinsi dengan produksi tertinggi adalah Jawa Tengah sebesar 481.890 ton dan disusul oleh Provinsi Jawa Timur sebesar 407.877 ton (BPS, 2020).

Produksi bawang merah di Indonesia cenderung mengalami peningkatan setiap tahunnya. Akan tetapi peningkatan produksi bawang merah di Indonesia belum mampu memenuhi kebutuhan dalam negeri. Akibatnya harga bawang merah dipasarkan cenderung fluktuatif dan dapat mengakibatkan inflasi karena pasokan bawang merah di pasar berkurang. Inflasi yang tinggi dan tidak menentu memberikan implikasi pada menurunnya pendapatan riil konsumen, menciptakan ketidakpastikan perilaku konsumen, dan terciptanya biaya yang tinggi dalam kegiatan ekonomi (Kustiari, 2017). 


\section{VOLUME 13, NOMOR 1, APRIL 2021}

Pranata dan Umam (2015) menyatakan bahwa harga bawang merah dengan produksi bawang merah memiliki hubungan negatif. Ketika harga bawang merah naik maka produksi bawang merah akan turun begitu pula sebaliknya maka keuntungan yang diperoleh petani akan kecil. Sehingga pada masa tanam selanjutnya tidak dapat menanam lebih banyak lagi. Fluktuasi harga bawang merah terjadi pada saat awal masa tanam atau juga kadang disebabkan adanya serangan hama atau penyakit yang massif. Selain itu kurangnya pasokan akibat jalur distribusi yang terganggu juga menjadi penyebab kelangkaan bawang merah di pasar dan menyebabkan harga bawang merah menjadi mahal (Putri dan Watemin, 2014).

Ketidakstabilan harga bawang merah akan memberikan dampak bagi produsen dan konsumen. Produsen menerima risiko terlalu tinggi dengan ketidakpastian harga pasar ketika panen sedangkan konsumen juga akan mengalami penurunan daya beli ketika harga bawang merah mahal. Oleh sebab itu diperlukan analisis peramalan harga bawang merah supaya tersedia data perkiraan harga yang akan terjadi di pasar. Dengan adanya peramalan harga yang akurat dapat menjadi acuan bagi petani dalam memasarkan produknya ke ke pedagang atau konsumen akhir. (Rasyidi,2017). Salah satu metode peramalan atau peramalan adalah dengan menggunakan ARIMA (Autoregressive Integrated Moving Average) dengan model Box-Jenkins. Berbagai penelitian dengan menggunakan ARIMA dengan model Box Jenkins adalah sebagaimana yang telah dilakukan oleh Guha dan Bandyopadhyay (2016) tentang peramalan harga emas dengan menggunakan model ARIMA. Penelitian yang dilakukan oleh Darekar dan Reddy (2017) yang telah melakukan penelitian tentang peramalan harga padi di India dengan menganalisis data padi selama 11 tahun dari Januari 2006 sampai Desember 2016. Penelitian tentang peramalan produksi teh hijau dengan pendekatan autoregressive integrated moving average juga telah dilakukan oleh Wijaksono dan Sulistijani (2017). Penelitian dengan menggunakan metode ARIMA juga sudah dilakukan oleh Pratiwi dan Al Rosyid (2019) yang menganalsis harga konsumen cabai merah besar dan cabai merah keriting di Daerah Istimewa Yogyakarta dalam kurun waktu Juli 2019 sampai Oktober 2019.

Berdasarkan latar belakan tersebut maka penelitian ini dilakukan untuk melakukan peramalan harga konsumen bawang merah di Provinsi Jawa Tengah.

\section{METODE PENELITIAN}

Metode analisis yang digunakan dalam penelitian ini adalah metode analisis deskriptif. Metode analisis deskriptif menurut Nazir (1988) mempunyai tujuan untuk memberikan deskripsi, gambaran, ilustrasi secara sistematis, berdasarkan fakta yang ada, sifat-sifat dan korelasi antara fenomena yang diamati. Analisis deskriptif yang digunakan dalam penelitian ini untuk menjawab tujuan penelitian yaitu melakukan peramalan harga konsumen bawang merah di Provinsi Jawa Tengah. Data yang digunakan dalam penelitian ini adalah data harga konsumen yang diperoleh dari aplikasi Pusat Informasi Harga Pangan Strategis (PIHPS) yang diakes pada lama hargapangan.id. Data yang digunakan untuk analisis ARIMA merupakan data harga konsumen bawang merah di Provinsi Jawa Tengah dari Bulan Juli tahun 2017 sampai Bulan April tahun 2021 dengan total jumlah data adalah 46 data harga konsumen. Analisis untuk mengetahui ramalan harga bawang merah di tingkat konsumen bawang merah di Provinsi Jawa Tengah menggunakan Metode Box-Jenkins (ARIMA).

Terdapat beberapa tahapan dalam melakukan analisis perediksi dengan menggunakan metode Box-Jenkins, yaitu (Winarno, 2015):

\section{Identifikasi Model}

Identifikasi model dilakukan untuk menentukan apakah data time series yang akan digunakan bersifat stasioner atau tidak. Data yang akan diestimasi harus bersifat stasioner karena data yang stasioner akan menghasilkan model estimasi yang baik dan mendekati apa yang ada. Data time series yang tidak stasioner biasanya disebabkan oleh sifat autokorelasi dan heteroskedastisitas Data yang stasioner bila nilai rata-rata dan varian data time series tersebut tidak mengalami perubahan secara sistematik sepanjang waktu atau sebagian orang berpendapat yaitu bila rata-rata dan variannya konstan. Bila data yang akan dianalsis tidak stasioner maka dapat dirubahmenjadi data time series yang stasioner dengan metode pembedaan (differencing method). Selanjutnya data time series yang telah stasioner dilanjutkan dengan mengidentifikasi bentuk model yang akan digunakan. Tahap ini dilakukan dengan membandingkan koefisien 
autokorelasi dan autokorelasi parsial dengan distribusi untuk berbagai macam model ARIMA yang sesuai.

Apabila autokorelasi secara eksponensial melemah menjadi nol berarti terjadi proses AR, namun bila autokorelasi parsial melemah berarti terjadi proses ARIMA. Penghitungan jumlah koefisien autokorelasi dan autokorelasi parsial yang signifikan berbeda dari nol, maka dapat ditentukan derajat proses MA atau AR.

Pendekteksian stasioneritas data dapat dilakukan dengan cara berikut ini:

a. Grafik, yaitu menggunakan plot data sederhana jika data mendekati rerata dan tidak ada kecenderungan memiliki tren naik ataupun turun, maka disimpulkan data telah stasioner.

b. Correlogram, yaitu dengan melihat nilai ACF (autocorrelation function) dan PACF (partial autocorrelation function). Data yang stasioner dicirikan dengan nilai autokorelasi dan autokorelasi parsial menurun secara time lag.

c. Unit root test, yaitu dengan membandingkan nilai ADF secara mutlak dengan nilai test critical value atau batas daerah kritis. Bila $|\mathrm{ADF}|>\mid$ batas kritis $\mid$ maka data telah stasioner.

2. Estimasi

Selanjutnya setelah didapatkan data yang stasioner, selanjutnya dengan melihat correlogram untuk membentuk berbagai kemungkinan metode ARIMA yang sesuai. Cara melihat correlogram adalah dengan melihat correlogram pada 4 lag pertama.

$\mathrm{p}=(\mathrm{AR}) \quad:$ PACF terakhir keluar pada lag ke berapa

$\mathrm{d}=(\mathrm{I}) \quad$ : Differencing berjumlah berapa

$\mathrm{q}=(\mathrm{MA}) \quad:$ AFC terakhir keluar pada lag keberapa

sehingga didapatkan model-model hasil overfitting atau dengan metode trial and error yang akan diperoleh model yang selanjutnya dilakukan uji signifikansi parameter dengan ketentuan sebagai berikut:

$\mathrm{H}_{0} \quad=$ Parameter tidak signifikan masuk model

$\mathrm{H}_{1} \quad=$ Parameter signifikan masuk model

Dengan $\mathrm{H}_{0}$ ditolak jika $p$-value $<\alpha$

3. Diagnostic Checking

Tahap selanjutnya adalah diagnostic checking, tahap ini dilakukan setelah penduga parameter didapatkan agar model siap untuk dimanfaatkan untuk peramalan. Tahap ini dilakukan untuk menguji apakah model yang telah dispesifikasi secara benar atau apakah telah dipilih $\mathrm{p}, \mathrm{d}$, dan $\mathrm{q}$ yang telah benar. Tahapan ini dapat dilakukan dengan berbagai metode, yaitu:

a. Bila model dispesifikasi dengan benar, kesalahannya harus acak atau merupakan proses white noise atau antar error tidak berhubungan sehingga fungsi autocorrelation dari kesalahan tidak berbeda dari nol secara statistik.

b. Modified Box-Pierce (Ljung-Box) dapat digunakan untuk menguji apakah fungsi autocorrelation kesalahan semuanya tidak berbeda dari nol, rumus statistik metode ini adalah:

Dimana:

$$
Q=n(n+2) \sum \frac{r_{k}{ }^{2}}{n-k}
$$

$\mathrm{r}_{\mathrm{k}} \quad=$ koefisien autocorrelation kesalahan lag $\mathrm{k}$

$\mathrm{n} \quad=$ banyaknya observasi series stasioner

statistik Q mendekati distribusi chi-square dengan derajat bebas k-p-q. apabila statistik Q lebih kecil dibandingkan dengan nilai kritis chi-square seperti yang ada di dalam tabel, maka semua autocorrelation dianggap tidak berbeda dari nol atau model telah dispesifikasi dengan benar.

Apabila terdapat banyak model yang lolos diagnostic checking, maka dipilih model yang terbaik dengan melihat koefisien yang paling sedikit sesuai dengan prinsip parsimony. Apabila penerapan prinsip ini masih saja menyisakan lebih dari satu model maka yang dipilih adalah model yang memiliki nilai Mean Square Error (MSE) yang paling kecil. MSE yang paling kecil menunjukkan model tersebut paling sesuai dengan data. Bila MSE dari model-model tersebut tidak memperlihatkan perbedaan yang menonjol, maka semua model dipilih dan diseleksi berdasarkan hasil ex post forecast. 
4. Peramalan (Forecasting)

Apabila model yang terbaik telah ditentukan, maka model tersebut telah siap untuk digunakan dalam peramalan. Model yang terbaik ditentukan dengan melihat nilai MAPE (Mean Absolute Pecent Error) sebagai nilai kesalahan dari nilai aktual $\left(\mathrm{Y}_{\mathrm{t}}\right)$ dengan nilai peramalan $\left(\mathrm{F}_{\mathrm{t}}\right)$.

\section{HASIL DAN PEMBAHASAN}

Tahapan dalam analisis ARIMA dengan menggunakan menggunakan metode BoxJenkins adalah dengan melakukan identifikasi model. Identifikasi model dilakukan untuk mengetahui apakah data time series yang akan dianalsis bersifat stasioner atau tidak. Maka dalam penelitian ini metode yang digunakan untuk melihat apakah data yang akan dianalisis bersifat stasioner atau belum dengan menggunakan uji akar unit (Unit Root Test) dan dengan menggunakan tabel correlogram.

Tabel 1. Uji Stasioneritas dengan Unit Root Test

\begin{tabular}{lccc}
\hline & & t-Statistic & Prob.* \\
\hline Augmented Dickey-Fuller test statistic & & -5.687432 & 0.0000 \\
Test critical values: & $1 \%$ level & -3.592462 & \\
& $5 \%$ level & -2.931404 & \\
& $10 \%$ level & -2.603944 & \\
\hline
\end{tabular}

Sumber: Harga Pangan (diolah), 2021

Berdasarkan correlogram serta uji unit root pada level 1 dapat diketahui data sudah bersifat stasioner karena nilai nilai ADF test statistic |-5.687432| > t-test 5\% sebesar -2.931404|. Oleh karena itu analisis ini dapat dilanjutkan pada tahap berikutnya yaitu identifikasi model untuk menemukan model terbaik yang akan digunakan dalam proses forecasting atau prediksi harga konsumen bawang merah di Provinsi Jawa Tengah.

\begin{tabular}{|c|c|c|c|c|c|c|c|}
\hline Autocorrelation & Partial Corr & rrelation & & $\mathrm{AC}$ & PAC & Q-Stat & Prob \\
\hline । 口। & । & & 1 & 0.235 & 0.235 & 2.6586 & 0.103 \\
\hline $1 \square \quad 1$ & $\square$ & 1 & 2 & -0.270 & -0.344 & 6.2427 & 0.044 \\
\hline$\square \quad$ । & 10 & 1 & 3 & -0.310 & -0.173 & 11.086 & 0.011 \\
\hline 1 С 1 & 10 & 1 & 4 & -0.138 & -0.119 & 12.066 & 0.017 \\
\hline 171 & & 1 & 5 & 0.087 & 0.011 & 12.470 & 0.029 \\
\hline $1[1$ & 10 & 1 & 6 & 0.027 & -0.146 & 12.509 & 0.052 \\
\hline 10 & 1 - & 1 & 7 & -0.114 & -0.152 & 13.234 & 0.067 \\
\hline $1 \square$ & $\square$ & 1 & 8 & -0.249 & -0.291 & 16.779 & 0.032 \\
\hline 1 당 & 1맘 & 1 & 9 & -0.172 & -0.246 & 18.507 & 0.030 \\
\hline 101 & 1믄 & 1 & 10 & 0.056 & -0.201 & 18.699 & 0.044 \\
\hline । $\square$ & 10 & 1 & 11 & 0.264 & -0.052 & 23.049 & 0.017 \\
\hline $1 \square$ & 1 & 1 & 12 & 0.296 & 0.040 & 28.649 & 0.004 \\
\hline $1 \sqrt{1}$ & 16 & 1 & 13 & 0.126 & 0.068 & 29.699 & 0.005 \\
\hline $1 \quad 1$ & 16 & & 14 & 0.008 & 0.151 & 29.704 & 0.008 \\
\hline 1 & 1 든 & 1 & 15 & -0.223 & -0.162 & 33.211 & 0.004 \\
\hline 10 & 17 & 1 & 16 & -0.120 & 0.003 & 34.266 & 0.005 \\
\hline 1 & 10 & 1 & 17 & 0.014 & -0.083 & 34.280 & 0.008 \\
\hline 10 & 10 & 1 & 18 & -0.057 & -0.159 & 34.532 & 0.011 \\
\hline 111 & 17 & & 19 & 0.025 & 0.112 & 34.581 & 0.016 \\
\hline 101 & $1 \llbracket$ & 1 & 20 & -0.089 & -0.035 & 35.252 & 0.019 \\
\hline
\end{tabular}

Gambar 1. Gambar Tabel Correlogram Harga Konsumen Bawang Merah di Provinsi Jawa Tengah

Pemilihan model terbaik telah dilakukan melalui hasil unit root test dan correlogram. Dari hasil tersebut diperoleh bahwa model sudah stasioner pada level 1. Selanjutnya pemilihan model terbaik dipilih berdasarkan model yang tidak mengandung autokorelasi, bersifat homoskedastisik dan berdistribusi normal. Pemilihan model terbaik juga dilakukan dengan melihat hasil regresi dengan melihat nilai Adj. $\mathrm{R}^{2}, \mathrm{R}^{2}$ yang paling besar dan berdasarkna nilai SE, AIC dan SIC yang paling kecil. Sehingga berdasarkan kriteria-kriteria tersebut maka nantinya diharapkan akan diperoleh model yang terbaik dan model ARIMA yang telah dipilih dan paling memungkinkan menjadi model yang terbaik adalah model dengan kombinasi sebagaimana berikut ini: 


\section{VOLUME 13, NOMOR 1, APRIL 2021}

1. ARIMA C $(2,1,4)$

2. ARIMA C $(3,1,2)$

3. ARIMA C $(3,1,3)$

Selanjutnya pada ketiga kombinasi model tersebut dilakukan diagnostic checking yaitu dengan melakukan analisis untuk melihat apakah model tersebut berdistribusi normal, bersifat homoskedastisitas dan terbebas dari autokorelasi. Berdasarkan hasil diagnostic checking diketahui ketiga model yang sudah dipilih merupakan model yang terbaik dimana model bersifat homoskedastisitas, terbebas dari autokorelasi, dan berdistribusi normal. Oleh karena itu tahapan selanjutnya untuk memilih model yang terbaik maka dilakukan pembandingan dari hasil regresi dengan melihat nilai Adj. $\mathrm{R}^{2}, \mathrm{R}^{2}$, SE, SIC, dan AIC seperti pada tabel 2.

Tabel 2. Kriteria Pemilihan Model ARIMA Terbaik Harga Konsumen Bawang Merah di Provinsi Jawa Tengah

\begin{tabular}{|c|c|c|c|c|c|c|c|}
\hline No & $\begin{array}{l}\text { Model } \\
\text { Terbaik }\end{array}$ & $\mathbf{R}^{2}$ & $\begin{array}{l}\text { Adj } \\
\mathbf{R}^{2}\end{array}$ & $\begin{array}{c}\text { S.E. of } \\
\text { Regression }\end{array}$ & $\begin{array}{c}\text { Log } \\
\text { likelihood }\end{array}$ & AIC & SIC \\
\hline 1 & $\begin{array}{l}\text { ARIMA } \\
\mathrm{c}(2,1,4)\end{array}$ & 0,189 & 0,1290 & 4709,356 & $-442,762$ & 19,8561 & 20,0167 \\
\hline 2 & $\begin{array}{l}\text { ARIMA } \\
\mathrm{c}(3,1,2) \\
\text { ARIMA }\end{array}$ & 0,210 & 0,1530 & 4645,412 & $-442,231$ & 19,8325 & 19,9931 \\
\hline 3 & $\begin{array}{l}\text { ARIMA } \\
\mathrm{c}(3,1,3)\end{array}$ & 0,214 & 0,1570 & 4633,921 & $-444,054$ & 19,9135 & 20,0741 \\
\hline
\end{tabular}

Sumber: Harga Pangan (diolah), 2021

Berdasarkan tabel 2. Diketahui bahwa model yang terbaik di antara model-model yang ada dengan memilih nilai Adj. $\mathrm{R}^{2}$ dan $\mathrm{R}^{2}$ yang paling besar, serta nilai Akaike Info Criterion (AIC), Schwarz Criterion (SIC), dan SE yang paling rendah. Dapat diketahui pada tabel 2. bahwa terdapat dua model yang memiliki kriteria yang bertolak belakang yaitu model ARIMA c $(3,1,3)$ dan model ARIMA c $(3,1,2)$ dimana model ARIMA c $(3,1,3)$ memiliki Adj. $R^{2}$ dan $R^{2}$ yang paling besar tetapi nilai AIC dan SIC bukan yang paling kecil sedangkan model ARIMA c $(3,1,2)$ memiliki nilai AIC dan SIC yang paling kecil tetapi Adj. $\mathrm{R}^{2}$ dan $\mathrm{R}^{2}$ bukan yang paling besar. Berdasarkan kondisi tersebut maka dipilihlah model ARIMA $\mathrm{c}(3,1,2)$ menjadi model yang terbaik dari antara model yang ada sebagaimana yang dinyatakan (Aprilia, et.al, 2017); (Putri dan Aghsilni, 2019) bahwa pemilihan model terbaik dipilih dari model yang memiliki nilai AIC dan SIC terkecil. Sehingga model ARIMA c $(3,1,2)$ didasarkan pada nilai Akaike Info Criterion (AIC) yang paling kecil yaitu19,8325, Schwarz Criterion (SIC) yang paling rendah yakni 19,9931. oleh karena itu model ARIMA c $(3,1,2)$ selanjutnya digunakan sebagai model untuk proses forcasting atau prediksi harga konsumen bawang merah di Provinsi Jawa Tengah.

Tabel 3. Output Regresi Harga Konsumen Bawang Merah di Provinsi Jawa Tengah dengan Model ARIMA c $(3,1,2)$

\begin{tabular}{lrlrr}
\hline \multicolumn{1}{c}{ Variabel } & Koefisien & \multicolumn{1}{c}{ Std. Error } & t-Statistic & Prob. \\
\hline C & 156.4233 & 275.9852 & 0.566781 & 0.5740 \\
AR(3) & -0.254657 & 0.143065 & -1.780011 & 0.0825 \\
MA(2) & -0.586703 & 0.144145 & -4.070220 & 0.0002 \\
SIGMASQ & 19661642 & 5191189. & 3.787503 & 0.0005 \\
& & & & 48.88889 \\
R-squared & 0.210930 & Mean dependent var & & 5048.149 \\
Adjusted R-squared & 0.153194 & S.D. dependent var & & 19.83247 \\
S.E. of regression & 4645.412 & Akaike info criterion & & 19.99306 \\
Sum squared resid & $8.85 E+08$ & Schwarz criterion & & 1.59234 \\
Log likelihood & -442.2306 & Hannan-Quinn criter. & & \\
F-statistic & 3.653308 & Durbin-Watson stat & & \\
Prob(F-statistic) & 0.020088 & & &
\end{tabular}

Sumber: Harga Pangan (diolah), 2021 
Berdasarkan hasil analisis regresi pada tabel 3. menunjukkan hasil arima $\mathrm{c}(3,1,2)$ memiliki persamaan $\mathrm{D}(\mathrm{Y})=-0.254657 \mathrm{AR}_{(3)}-0.586703 \mathrm{MA}_{(2)}$. Output regresi dari model ARIMA c $(3,1,2) \mathrm{AR}(3)$ dan MA(2) mempengaruhi harga konsumen bawang merah di Provinsi Jawa Tengah.

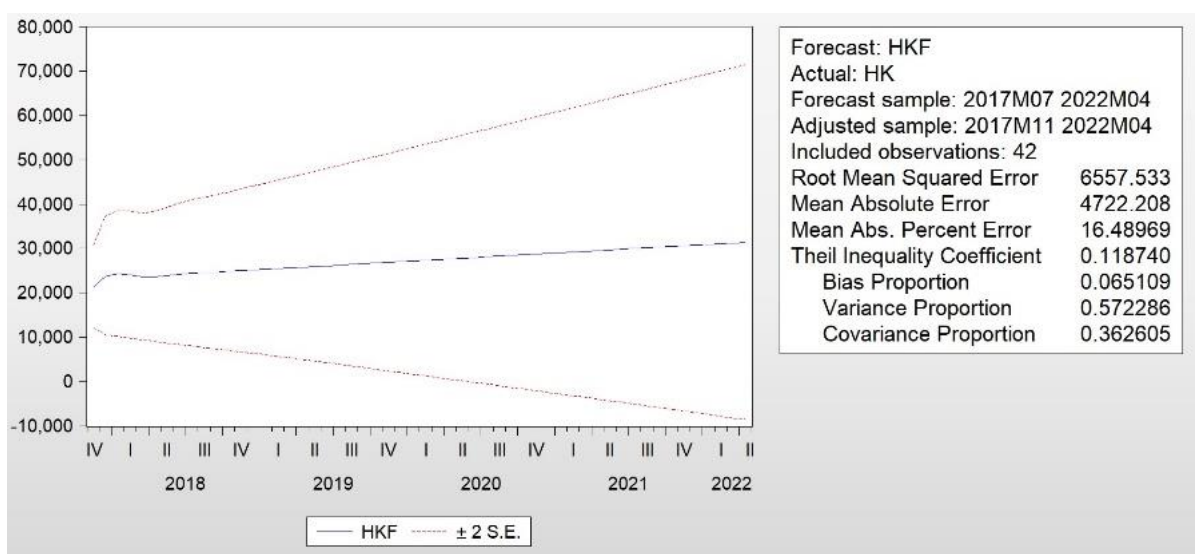

Gambar 2. Grafik Hasil Forcasting Harga Konsumen Bawang Merah Model ARIMA c $(3,1,2)$ dengan Metode Dinamis di Provinsi Jawa Tengah

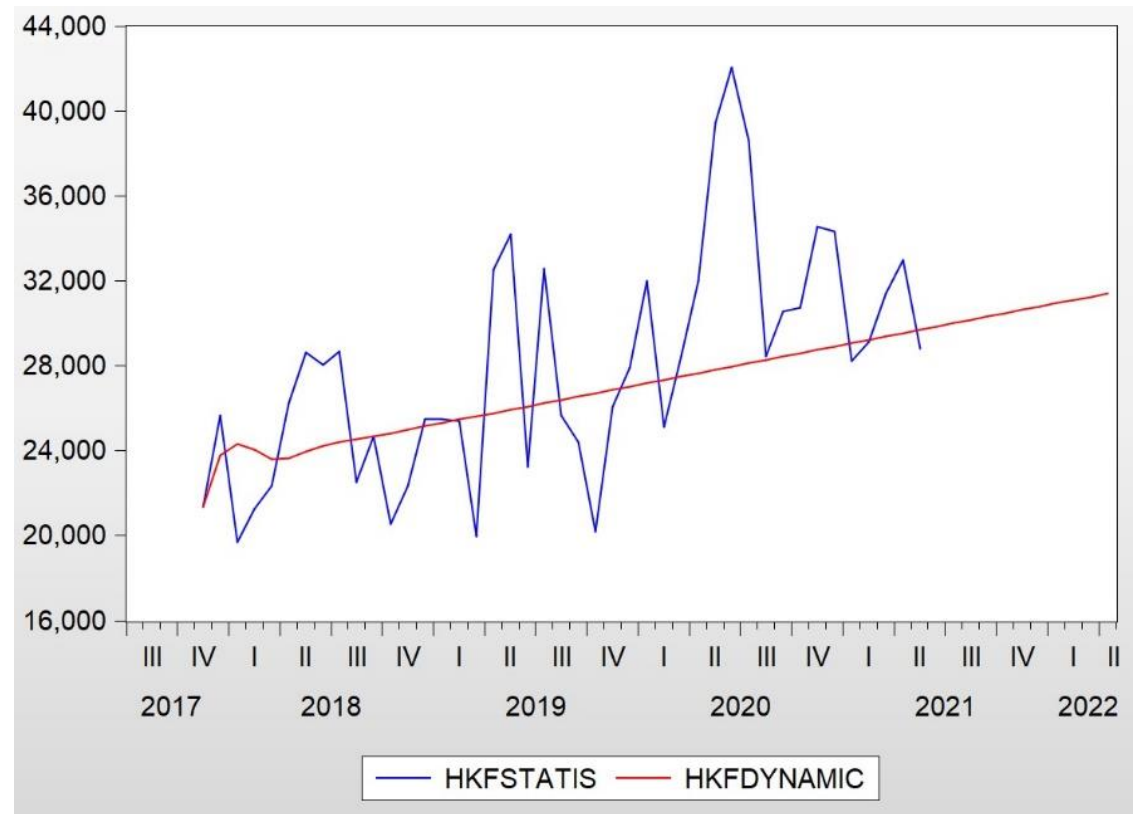

Gambar 3. Grafik Hasil Forcasting Dinamis dan Statis Harga Konsumen Bawang Merah dengan Model ARIMA c $(3,1,2)$ di Jawa Tengah

Berdasarkan grafik hasil forcasting dinamis dan statis dapat diketahui bahwa harga konsumen bawang merah di Provinsi Jawa Tengah dari tahun 2017 sampai tahun 2022 cenderung terus meningkat. Peningkatan harga bawang merah ini disebabkan oleh permintaan bawang merah yang terus meningkat setiap tahunnya. Peningkatan permintaan bawang merah belum dapat diimbangi oleh peningkatan produksi bawang merah, sehingga terjadi kekurangan pasokan bawang merah di pasar yang menyebabkan kenaikan harga konsumen. 
Tabel 3. Tabel Hasil Forcasting Harga Konsumen Bawang Merah di Jawa Tengah ARIMA c $(3,1,2)$ Metode Dinamis

\begin{tabular}{|c|c|c|}
\hline Tahun & Bulan & Harga Konsumen Bawang Merah (Rupiah) \\
\hline \multirow{12}{*}{2020} & Januari & 27.188 \\
\hline & Februari & 27.345 \\
\hline & Maret & 27.501 \\
\hline & April & 27.657 \\
\hline & Mei & 27.814 \\
\hline & Juni & 27.970 \\
\hline & Juli & 28.127 \\
\hline & Agustus & 28.283 \\
\hline & September & 28.439 \\
\hline & Oktober & 28.596 \\
\hline & November & 28.752 \\
\hline & Desember & 28.909 \\
\hline \multirow{12}{*}{2021} & Januari & 29.065 \\
\hline & Februari & 29.222 \\
\hline & Maret & 29.378 \\
\hline & April & 29.534 \\
\hline & Mei & 29.691 \\
\hline & Juni & 29.847 \\
\hline & Juli & 30.004 \\
\hline & Agustus & 30.160 \\
\hline & September & 30.317 \\
\hline & Oktober & 30.473 \\
\hline & November & 30.629 \\
\hline & Desember & 30.786 \\
\hline \multirow{4}{*}{2022} & Januari & 30.942 \\
\hline & Februari & 31.099 \\
\hline & Maret & 31.255 \\
\hline & April & 31.412 \\
\hline
\end{tabular}

Sumber: Harga Pangan (diolah), 2021

Berdasarkan hasil prediksi diketahui bahwa harga konsumen bawang merah di Provinsi Jawa Tengah cenderung meningkat dari tahun 2020 sampai pada tahun 2022 tepatnya pada Bulan April. Kondisi ini menunjukkan bahwa harga konsumen bawang merah di Provinsi Jawa Tengah, dimana merupakan provinsi pemasok bawang merah terbesar di Indonesia, memiliki kecenderungan pola harga konsumen yang terus meningkat setiap tahunnya. Kondisi ini disebabkan oleh semakin meningkatnya permintaan bawang merah di Provinsi Jawa Tengah khususnya dan di daerah-daerah lain pada umumnya yang belum dapat diimbangi dari produksi bawang merah. Kenaikan harga bawang merah biasanya terjadi pada selain panen raya, khususnya saat menjelang panen raya sehingga penawaran bawang merah mengikuti harga bawang merah yang cenderung meningkat. Akan tetapi pada saat panen raya jumlah bawang merah yang ditawarkan oleh produsen lebih banyak dibandingkan dengan yang diminta oleh konsumen, sehingga mengakibatkan penurunan harga konsumen bawang merah (Stato, 2007). 


\section{KESIMPULAN DAN SARAN \\ Kesimpulan}

Berdasarkan hasil penelitian dapat disimpulkan bahwa model ARIMA terbaik yang digunakan untuk prediksi harga konsumen bawang merah di Provinsi Jawa Tengah adalah ARIMA c $(3,1,2)$. Model harga konsumen bawang merah di Provinsi Jawa Tengah adalah $\mathrm{D}(\mathrm{Y})=-0.254657 \mathrm{AR}_{(3)^{-}}$ $0.586703 \mathrm{MA}_{(2)}$. Prediksi harga konsumen bawang merah di Provinsi Jawa Tengah sampai Bulan April tahun 2022 dengan menggunakan metode dinamis diperoleh data harga konsumen yang terus meningkat secara perlahan-lahan.

\section{Saran}

Harga konsumen bawang merah di Provinsi Jawa Tengah khususnya, dan di Indonesia pada umumnya cenderung flukatuatif dan trennya semakin meningkat. Semakin meningkatnya harga konsumen bawang merah disebabkan oleh permintaan bawang merah yang semakin meningkat. Maka pemerintah perlu memberikan inovasi-inovasi program selain untuk meningkatkan produksi bawang merah, juga supaya ketersediaan bawang merah cukup stabil di pasar. Yaitu dengan memperluas daerah sentra bawang merah di Indonesia dengan pengaturan pola tanam yang dibuat supaya bawang merah terus tersedia sepanjang tahun. Selain itu perlu adanya dorongan berbagai pihak untuk menciptakan tekonologi pengawetan dan atau penyimpanan bawang merah yang murah supaya petani mudah untuk menyimpan bawang merahnya.

\section{Ucapan Terima Kasih}

Penulis mengucapkan terimakasih yang sebanyak-banyaknya kepada semua pihak yang telah membantu dan mendukung, baik dari pendanaan, waktu dan tenaga. Sehingga penelitian ini dapat terlaksana dengan baik.

\section{DAFTAR PUSTAKA}

Aprilia A.E., Soehardjoepri, Widjajati, F.A. 2017. Estimasi Risiko Investasi Saham di Sektor Keuangan Menggunakan ARCH-GARCH. Jurnal Sains dan Seni ITS. 6 (2): 83-87.

Badan Pusat Stastistik. 2020. PDB Triwulanan Atas Dasar Harga Konstan 2010 Menurut Lapangan Usaha (Miliar Rupiah), 2019-2020. BPS : Jakarta (ID).

Darekar, A and Reddy, A.A. 2017. Forecasting of Common Paddy Prices in India. Journal of Rice Research. 10 (1): 71-75.

Guha, B. and Bandyopadhyay, G. 2016. Gold Prices Forecasting Using ARIMA Model. Journal of Advanced Management Science. 4 (2): 117-121.

Kustiari, R. 2017. Perilaku Harga dan Integrasi Pasar Bawang Merah di Indonesia. Jurnal Agro Ekonomi. 35. (1): 77-87.

Pratiwi, LFL and Al Rosyid, A.H. 2020. Forecasting of Chili Prices in The Special Region of Yogyakarta, Indonesia Based in Harga Pangan Applications (Arima Approach). Proceeding International Conference on Green Agro-Industry (4):39-47.

Putri, A.M. dan Aghsilni, 2019. Estimasi Model Terbaik untuk Peramalan Harga Saham PT. Polychem Indonesia Tbk. Dengan Arima. Mathematics \& Applications Journal. 1(2):1-12. 
Putri, R.H. dan Watemin. 2014. Analisis Trend dan Estimasi Harga Bawang Merah di Kabupaten Banyumas Periode Januari 2018- Desember 2017. Jurnal Dinamika Ekonomi dan Bisnis. 11 (1): 65-69.

Pranata, A. dan Umam A.T., 2015. Pengaruh Harga Bawang Merah Terhadap Produksi Bawang Merah di Jawa Tengah. Jurnal of Economic and Policy. 8 (1) 36-44.

Rasyidi, M.A., 2017. Prediksi Harga Bahan Pokok Nasional Jangka Pendek Menggunakan ARIMA. Journal of Information System and Business Intelligence. 3 (2):107-112.

Stato, Hapto. 2007. Analisis Faktor-Faktor Yang Mempengaruhi Fluktuasi Harga Bawang Merah Dan Peramalannya (Studi Kasus Pasar Induk Kramat Jati, DKI Jakarta). Skripsi. Bogor: IPB.

Wijaksono, S. dan Sulistijani, W. 2017. Peramalan Produksi The Hijau dengan Pendekatan Autoregressive Integrated Moving Average. Seminar Nasional Pendidikan, Sains, dan Teknologi Fakultas Matematika dan Pengetahuan Alam Universitas Muhammadiyah Malang.

Winarno, W. W. 2015. Analisis Ekonometrika dan Statistika dengan Eviews Edisi 4. UPP STIM YKPN. Yogyakarta. 